\title{
OLD ZION CHURCH, BURLINGTON, IOWA.
}

\author{
BY EDMUND H. WARING, D. D.
}

This honored and somewhat noted edifice has had a very remarkable history, connected with the early annals of the Territory of Iowa, as well as with the Methodist Episeopal Chureh. Perhaps no western edifice has witnessed more remarkable scenes, or been devoted to more diverse uses. And besides these distinctions it was the first brick church built in the limits of the State, and at the time when it was dismantled was the oldest house of worship then in use in Iowa.

Contrary to what is usually the case, the materials for a very complete account of Old Zion are extant. The early records, for which we are indebted to the careful forethought of Rev. N. S. Bastion, the first stationed preacher of the ehurch in Burlington, were kept with eonsiderable completeness, and have been preserved.

The principal actor in the erection of Old Zion was Dr. William R. Ross. Ross was one of the first settlers at Flint Hills, as that vicinity was then called. He was on the ground when there was nothing there but a string of cabins at the landing, which was known as Pin Hook. In 1833 he brought the first stock of goods to the place. There were a number of honorable "firsts" to his name. He was the first postmaster, justice, and clerk of the court there. Through him the first preacher, Rev. Barton H. Cartwright, was secured, and he appears to have been the first man of the settlers to get married. But in accomplishing this purpose he had trouble. He found the lady, but Pin Hook contained no person authorized to perform the needed ceremony. But "love laughs at locksmiths." A justice was brought from Monmouth, Ill., and Ross, taking his bride across the river 


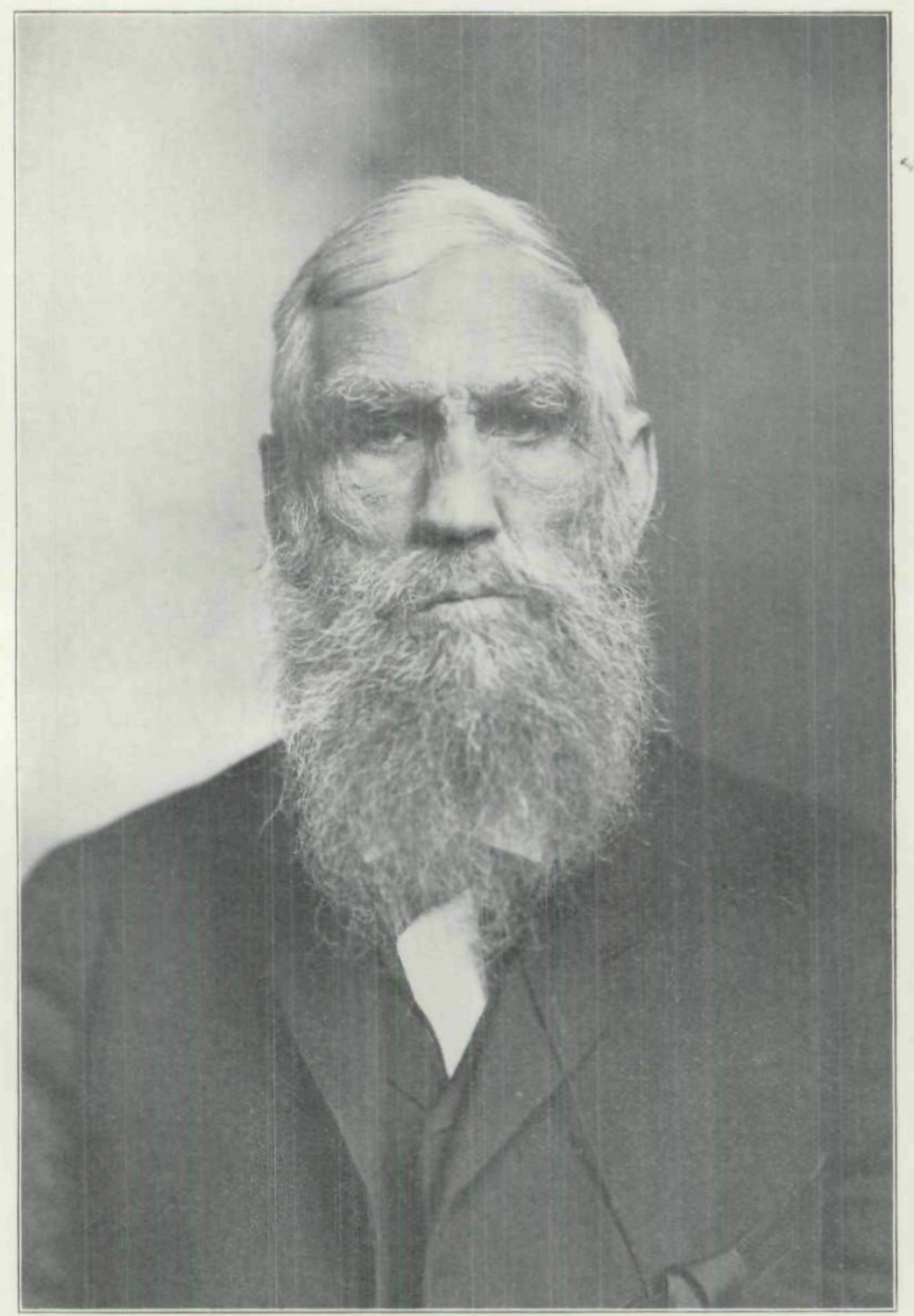

REV. E. H. WARING. 
in a skiff, was married in the open on the Illinois shore. Of him that other worthy Burlington pioneer, lately called away, Dr. William Salter, said:

"Dr. Ross built several eabins in 1833. He was public spirited and a warm hearted Methodist. $\mathrm{He}$ was the first postmaster of the town. It was five years ago he told me that the school and church were residents in 1834, and he was the right hand man of the teacher and the preacher. And one of his eabins furnished the place with a schoolhouse. He built Old Zion, which was free to order for preaching. His work and services not only resulted in the large and flourishing Methodist church that has grown out of his labors; but it is also in all the churches and schools that have been built from that time to this."

He might have added that the early Methodist preaching there by Cartwright was in Dr. Ross's eabin, on the north hill, the yard being frequently filled with Indians during the service. This worthy man died some years since at Lovilla, Iowa, at a very advanced age. Dr. Ross bought the two lots on which the church and parsonage stood for one hundred dollars, and donated them to the society. In 1836 he dug the cellar, or rather excavated from the hill nearly the whole of the south lot, for the building, at a cost of $\$ 72.00$, the only aid being $\$ 20.00$, given by David Rorer, a pioneer lawyer of the town. The next year, 1838, the work on the church was commenced; but the progress, for want of means, was slow. The old record book has the minutes of a meeting held March 5th, 1838, at Mr. Chapman's room, "to take into eonsideration the erection of a meeting house." The pastor, Rev. N. S. Bastion, J. C. Sleeth, Thomas Ballard, Levi Hagar, Wm. Davis and Wm. R. Ross were present. It was resolved to build a house of brick, 40 by 60 feet in size, and Sleeth, Ross and Hagar were named as a building committee. Preeise instructions were given the committee. They were: "1. To estimate the probable expense. 2. To raise funds. 3 . To plan said building. 4. To let out and make all contracts, and for security to have a lien on the building. 5. To exer- 
cise a general superintendence over the work until completed. 6. To have power to make their own regulations, and to fill vacancies in their number oceasioned in any way." Certainly their duties were plain, and their powers ample.

The quarterly conference, which met on March 10th, and was composed of the same parties, with the addition of the presiding-elder, confirmed the appointment of the committee, and added Adam Fortney to their number. The committee held frequent meetings, in which plans, specifications and proposals of the mechanies were fully discussed and a contract for the brick was made with Dr. Ross, June 15th, 1838, at the rate of $\$ 7.50$ per thousand. The contract for the stone was made with parties styled "the Germans," at the rate of "one dollar for every $221 / 2$ eubic feet, to be measured clear measure when in the wall.". The walls of the basement were to be two feet thick, and it was to have "doors and windows sufficient to make it light and airy, so that the rooms would be pleasant and comfortable for meetings and schools." But this the situation of the church, dug out of the steep hill side, effectually prevented. March 7th, 1838, the form of the subscription was agreed upon; but the list of subseribers is lost. The probable cost of the house, "partially completed," was stated at from two to three thousand dollars. Under date of April 2nd, 1838, Mr. Bastion says: "The contracts for the stone, lime, lumber, brick, timber and digging are all let. See list of contracts in this book." But the list is missing. The work upon the church, under these arrangements, was commenced in April or May, 1838.

June 14th, 1838, the following trustees were appointed: John C. Sleeth, W. R. Ross, Thomas Ballard, Robert Cock and Robert Avery. They met June 18th, 1838, and resolved "in their capacity of trustees to assume the responsibility of the business heretofore transacted by the building committee, and attend to the duties of their office," in view of which action Bastion records, June 25th, 1838, "the building committee is annihilated, and the trustees assume all the business and obligations." 
About this time a begging tour, in the interest of the project, was undertaken by Bastion. To foot the eurrent expenses of the trip Sleeth, Ross, Ballard and Hagar made up $\$ 30.00$, and Bastion went as far south as Louisville, Kentucky, where he had to borrow $\$ 25.00$ to pay his expenses home. And the balance sheet showed:

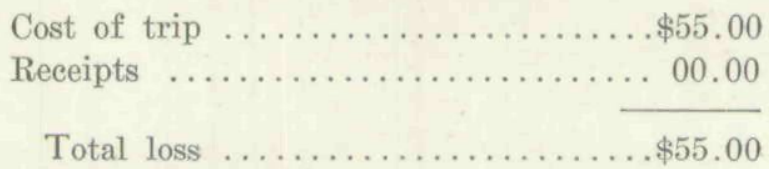

The Legislature of Wisconsin, then in session in Burlington, the Territorial Capital, passed an act of incorporation for the church, which was approved June 22nd, 1838. It provided that "John C. Sleeth, Thomas Ballard, Wm. R. Ross, Robert Avery and Robert Cock, and such other freewhite persons of full age as shall be associated with them, . . . shall be, and are hereby constituted and made a body corporate in deed and in law, by the name, style and title of the Trustees of the Methodist Episeopal Church in the eity of Burlington........... with perpetual succession, and are hereby made eapable in law to have, purchase, receive, take, hold, possess and enjoy, to them and their suceessors, to the tise of the said Methodist Episeopal Church in the City of Burlington, ............ Lot No. 374 and $375^{1}$."

The Southern prejudice, prevalent at the time, is indicated in the phrase "free white persons."

During the summer and fall of 1838 the building was pressed vigorously. In a report signed by John C. Sleeth and Robert Cock, in which they state the amount of the original subseription at $\$ 1,500.00$, they say: "After having proceeded with the building to a considerable extent, an opportunity presented itself of renting the church to the legislative assembly. Thinking this opportunity a favorable one for raising funds to pay the expense of erection, every effort was made to have it completed in time for that special purpose." This report was made to the quarterly conference,;

${ }^{1}$ Laws of Wisconsin Territory, 1838 , p. 346. 
March 6th, 1841. The proposition eame from Robert Lueas, Governor of the Territory of Iowa. The work on the church, so far as it had then been done, was finished in December, 1838. But nothing further had been accomplished than to enclose it, and put on one coat of plaster. And it then consisted of only the "old part." The front extension and cupola were not erected until 1846. A framed platform extended along the front of the chureh on a level with the audience room. It stood on turned posts, and was ascended from the street by a flight of steps. The building as completed thus, cost about $\$ 4,500.00$.

Perhaps this is a good place to say something about the pastor, Bastion, who lent his aid so efficiently in the furtherance of the work. He joined the Illinois Conference on trial in 1832. At the session of $\mathbf{1 8 3 4}$ he was admitted to full connection, ordained a deacon, and sent to Dubuque. He was a man of fair talents and good scholarship, zealous, and of excellent business eapacity; but erratic, irritable and given to change. At the close of his year at Dubuque he retired and taught school at Catfish Gap. There the school was often visited by the Indians, who could not understand why he was caring for other people's children, and who, in view of the apparent size of his family, gave him an Indian name, meaning Big Father. In 1837 he was sent to Burlington, then made a station. The next year he was appointed principal of the Preparatory Department of McKendree College. In 1849 he transferred to the Liberia Conference, Africa, of which he was the acting President in 1850. In 1851 he returned to America; but having become dissatisfied with his baptism, he did what he had a perfect right to do, withdrew from the Methodist Church, and so beeame lost to Methodist vision in the waters of a sound Baptist immersion.

The Territorial Legislature and government took possession of the church as soon as it was completed. The upper room was assigned to the House of Representatives, the front basement to the Senate. The rear basement was divided by rough board partitions, for the legislative and government offices. 


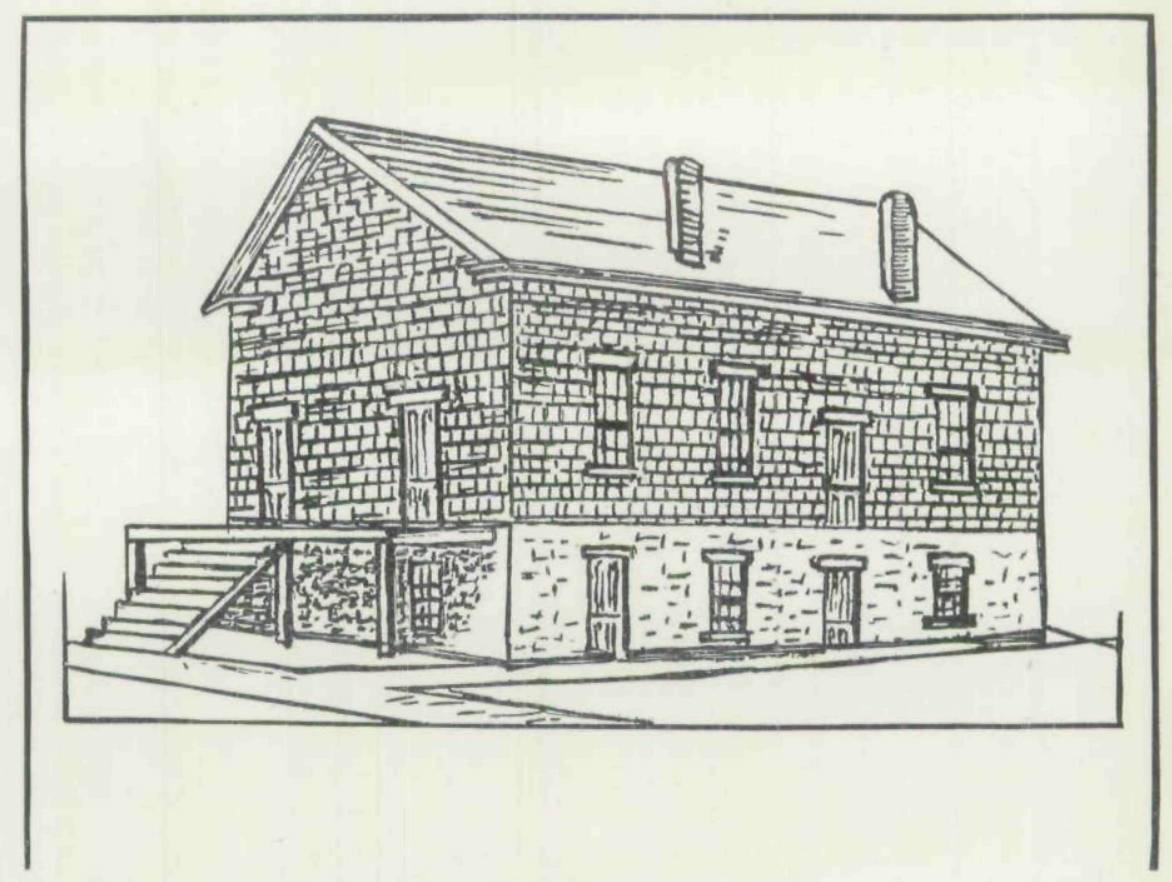

OLD ZION, THE FIRST CAPITOL OF IOWA.

From an unsigned drawing used in the semi-centennial celebration ceremonies at Burlington, 1896. 
Some long benches were provided for seats by the trustees; but the chairs used in the halls were purchased by the government. The Speakers' desks were made of boards, roughly planed, and nailed together so as to form a kind of stand; and the one in the audience room served, at time of preaching, as the pulpit. And so, it came to pass that, by the arrangement made, the Upper House of the Legislature was the Lower House, and the Lower House the Upper House! Amid such primitive surroundings the machinery of legislation was first put in motion in the Territory of Iowa.

In their report of 1841, the trustees gave their aggregate receipts to that date as follows: Received from the Legis. lature $\$ 2,200$. On subseription $\$ 980$. Total $\$ 3,180$. Remaining debt $\$ 1,320$. To meet this debt they had a balance of rent due of $\$ 300$, and subseriptions (depreciated) of about $\$ 500$, and the debt continued for some years to be a source of vexation and trouble. The late Rev. D. G. Cartwright informed me that while acting as a supply, as pastor of the church, in 1840, the building was threatened with sale; but he succeeded in getting a number of the creditors to release their claims, and in this way over $\$ 1,000$ of accumulated incumbrance was cleared off within two days. Dr. Ross said, "I paid for most of the material, rock, lime, lumber and all the brick, besides many other materials, and many of the workmen, eosting me upwards of six thousand dollars; and after all, to keep it from being sold at a sacrifice-for it had gone through a Court of Law and Equity, and the Conference -I had to sell my own private residence, which cost me $\$ 3,400$ for $\$ 1,200$, and save the church from sale." Through such embarrassments many of the pioneer churches of Iowa had to pass but few of them had behind them a man of the pluck, liberality and self-sacrifice shown towards Old Zion by Dr. Ross. And it is a pity to say that what he did for the old church seriously embarrassed him in his later years.

The Iowa Patriot of December 13th, 1838, said of the old building: "The new Methodist Church is now occupied by the Legislative Assembly. It is a very neat and substantial 
building. The basement story, partitioned off for conference and class-meetings, is composed of stone, and the upper part of brick. It is in a commanding situation, and when finished, with its cupola and bell, it will be a great ornament to the city of Burlington."

The location of Old Zion, on the west side of Third Street, between Washington and Columbia Streets, was central for the north side at the time. The claim to the town site was held by two brothers-in-law, White and Doolittle, and the church lots were purchased by Dr. Ross for one hundred dollars. The title to the lots, however, came to the trustees of the church through Bastion, who was held in a bond of $\$ 10,000$ to make the trustees a deed according to the provisions of the discipline of the M. E. Church, so soon as he should receive a patent from Washington. The duplicate of the certificate of title was placed in the hands of John C. Sleeth, to be sent to the land office; and the patent issued by the United States to the trustees is dated February 4, 1841.

The Legislature of the Territory of Iowa held four sessions in the church, viz: the regular sessions of 1838-39 and 183940 , the extra session of July, 1840, and the regular session of 1840-41. And the appropriation bills show that the territorial government paid the trustees, for the use of the house, in all $\$ 2,350$. Besides its use by the Legislature it was employed for several years as the place of meeting of the Supreme Court of Iowa, and the District Court of Des Moines County. While so used, in June, 1845, the Mormon murderers, the Hodges brothers, were tried and convieted there of murder in the first degree. The verdict of the jury was delivered on Sunday morning, June 22nd; and on the afternoon of that day they were sentenced to death from the pulpit of Old Zion, and were both hung July 15th following.

The church being at that time the only commodious building in the town, it was used for a long time as the place of political meetings, lectures and even shows. And during all that time the services of the Methodist Church were held within its walls, and frequently those of other denominations 
were held therein. And after its use was abandoned by the government, the basement was furnished with desks and private and public schools were accommodated there.

January 23rd and 24th, 1840, it was the scene of an Indian council held by Governor Lucas with the chiefs of the Sac and Fox Indians. About fifty of the Aborigines, including young Black Hawk, and the chiefs Wishelamaqua, or Hardfish, Wapapesheek, or the Prophet, and Nasheaskuk, all in their native eostumes, were present. They eame to complain of the desecration by the whites, of old Black Hawk's grave. And the whole affair wound up with a big war dance and Indian show.

On Monday night, December 16th, 1838, it was the headquarters of a company of soldiers from Muscatine, numbering about 150 , on their way to the threatened border war between Missouri and Iowa respecting the southern line of the Territory.

Four sessions of the Iowa Conference of the M. E. Chureh were held in Old Zion, viz.:

Date. Bishop. Secretary.

1845 T. A. Morris ................... W. Reed

1852 E. R. Ames...................... H. Hare

1861 Levi Scott................. H. Waring

1868 E. S. Janes.................. H. Waring

On account of its diverse uses, the building was known by different names, such as "The Methodist Church," "The Court House," and "The State House." Thus in The Iowa Patriot of Dec. 13th, 1838, a notice said: "A two days' meeting will be held in the State House in this city on Saturday evening next, and continuing until Sunday night."

The name "Old Zion" dates from 1851. In a notice in the Burlington Telegraph, attention was ealled to the need of a new roof on the church, and to give prominence to the matter, the editor headed the notice with the words "Old Zion needs a new roof." The name thus given was at once attached to the building, and in 1854 the station, organized in the church, was named the Old Zion station. 
In reference to the remarkable history of the old church, Hon. Charles Mason, in a speech delivered at an old settlers' festival in the church, June 2nd, 1858, said: "As illustrative of the novel uses to which it was necessary to adapt the limited means within our reach in those early days, and of the shifts to which we were driven by the great mother of invention, I need but remind you of the scenes which have been witnessed within these very walls. The main body of the edifice has now been standing about twenty years. It was the first, and for many years, the only church building in Burlington.

"Whoever, at the present day, sits within its hallowed precincts, listening to the fervid prayer, the calm discourse, the swelling anthem, or the loud hosanna, would be very erroneous in the conclusion that these were the only sounds that had ever echoed within it. No, other halls have witnessed more important and more tragical scenes; but where will you find those that could give a more variegated history? Here was embodied, for instance, for a number of years, the legislative wisdom of the Territory of Iowa-the "Lower" house paradoxically oceupying the hall above, and the "Upper" house the room below. From these went forth those edicts which for many years have ruled this goodly land. Here too the Supreme Judicial Tribunal of the Territory held its sometime session; and the regular terms of the District Court were held here for many a year. Here the rights of persons and property were adjusted. Here the felon trembled, and hoped at the prospect of an inefficient penitentiary, and here the murderer met his final earthly doom. Nor is this all. With the eye of vivid recollection I now see before me the assembled patriotism of the young city, in demoeratic council assembled, to discuss in high debate, the momentous question of peace or further war, with our more powerful, but not more valiant antagonist. A model war was that, and worthy of our praise, where not a drop of blood was shed, where those who won the glory paid the bills, and ever since their hearts have been inclined to peace. 
"Finally within these walls the amiable governor of the Territory met in friendly conference the representatives of some of the dissatisfied red children, to hear their complaints, and at least to promise them redress-an easy and oft repeated remedy.

"Here the eitizens listened to the native eloquence of the Indians, and were treated to the exhibition of the song and the war dance. The wild whoop of the savage, which had often carried dismay and horror to many a stout heart, failed to make any impression on Old Zion, which then as now, looked on in strange gravity, and was determined not to be surprised at any scene that might transpire within it." The war referred to was the contest over the boundary line between Missouri and Iowa.

And Old Zion has not wanted for a poet. At the Old Settlers' Festival spoken of, Johnson Pierson, Esq., read a poem, in which were the following lines:

"Now rose thy walls, Old Zion, which have stood The dread assaults of wasting Time and flood. Thou wast all our hope for many rolling years; Shook with our joy; as often soothed our tears, Poured out like rain drops from the smitten eloud, When the live, vaulting thunder rifts its shroud. Thou wert our Forum, scene of many a sport In Pleasure's drama and Ambition's court. Here too our village beauties rushed to see The motley Indian dance, with savage glee: Here was the patriot's stand when border war Chained his fieree dragons to the bloody ear. But our good guns and swords of burnished sheen, Showed we were brave-a set of dangerous men.

We 'went, saw', conquered'- not the foe - the meat Our knapsacks held - then made a grand retreat! We ran with eager haste from war's alarms, Covered with glory, to our shops and farms, To hear the plaudits, 'Patriots, well done.'

So thou, old pile, hast been our guiding star In all these varied scenes of Peace and War." 
After the chureh was abandoned by the Territory in 1840 , the members placed in the "Amen corners" some rough benches, with narrow backs. The rest of the house had just benches to be used as seats; but about 1845 it was furnished with comfortable pews. The first pulpit has been described. That was succeeded by a kind of tub concern that half encircled the preacher as he stood behind it. A third stand, a high and massive strueture, "marbleized," and thought tasteful in its day, was set up as the pulpit. When taken down in 1862 there was found peneiled inside of one of the columns, "August 22nd, 1845," But its day was brief, for in the thorough renewal of Old Zion in 1864 a neat, small stand of walnut took its place as the reading desk of the minister. On down to the year 1879 Old Zion, with a slight interruption in 1864, was used as the place of worship of the station. But in that year the two Methodist churches then in the city were united, and the services taken to the larger edifice on Division Street. Later the old property was sold, the new owners taking the old building, and the adjacent parsonage, down, and erecting on the site a theater. It may be that, in the change that eame over the growing city, a new site for the church became a desirable thing. Yet it seems sad that a spot where the people of God had so long gathered for worship, which had been solemnly dedicated to its sacred uses, and which had become hallowed by its associations in the memories of thousands, should now be given up to the giddy throng of fashion, intent alone upon ereature enjoyment, to the neglect of the higher duties that pertain to a better and safer life.

FUR Trapping IN Iowa.-The rivers and creeks in the interior and western parts of Iowa are said to be perfectly thronged with beavers and minks, to say nothing of myriads of other animals whose hides are sought by the trappers. Beaver Creek, which empties into the Cedar at Cedar Falls, is dammed at very frequent intervals by the industrious and enterprising rodents from which it takes its name. They have not been as plenty before for several years. The trapper's field of labor is a large one, and great numbers of them are "picking up their traps" and preparing to reap their harvest. Prices are likely to be remunerative.-Sioux City Register, Dec. 31, 1859. 
Copyright of Annals of Iowa is the property of State of Iowa, by \& through the State Historical Society of Iowa and its content may not be copied or emailed to multiple sites or posted to a listserv without the copyright holder's express written permission. However, users may print, download, or email articles for individual use. 